\title{
Monitoring mule deer diet quality and intake with fecal indices
}

\author{
THOMAS P. HODGMAN, BRUCE B. DAVITT, AND JACK R. NELSON
}

\begin{abstract}
Authors are wildlife research associate, Department of Wildlife Ecology, 5755 Nutting Hall-Rm 240, University of Maine, Orono, Maine 04469, research technologist supervisor, and professor, Department of Natural Resource Sciences, Washington State University, Pullman, Washington 99164. At the time of research, Hodgman was graduate research assistant, Department of Natural Resource Sciences, Washington State University, Pullman, Washington 99164.
\end{abstract}

\begin{abstract}
Few studies have evaluated fecal indices for monitoring diet quality and intake of North American deer. We conducted 11 digestion trials with black-tailed (Odocoileus hemionus columbianus Richardson) and mule deer $(O$. h. hemionus Rafinesque) to examine relationships between several chemical constituents of deer feces (i.e., fecal nitrogen, fecal 2,6diaminopimelic acid (DAPA), fecal neutral detergent fiber (NDF), fecal acid detergent fiber, and fecal acid detergent lignin) and dry matter intake, digestible energy, digestible energy intake, diet crude protein content, crude protein digestibility, and digestible crude protein intake. We developed regression equations to predict diet quality and intake and also evaluated 2 alternative methods (organic matter basis and neutral detergent fiber (ndf) basis) for quantifying fecal indices. Concentrations of DAPA, fecal NDF, and fecal $\mathbf{N}$ were the most precise for estimating diet quality and intake. Extracts from 5 of 11 diets precipitated only small amounts of protein and influence of tannins on protein digestion probably was slight. Quantifying fecal indices per unit organic matter and neutral detergent fiber in the feces was comparable to the standard dry matter basis and under some field conditions should improve their predictive ability. We believe our best equations are suitable for management purposes where diets are similar and intake and quality are believed to be within the ranges we documented.
\end{abstract}

Key Words: 2,6-diaminopimelic acid, DAPA, fecal nitrogen, fiber, predictive equations, Odocoileus hemionus, tannins

Monitoring the nutritional well-being of free-ranging deer has become an essential part of big game management. Several fecal indices have shown promise for providing information about diet quality of free-ranging deer (Kie and Burton 1984, Leslie and Starkey 1985, Hodgman and Bowyer 1986, Beier 1987, Leslie et al. 1989). One index, fecal 2,6-diaminopimelic acid (DAPA),

This project was funded by the U.S. Fish \& Wildlife Service, Nova - An Alberta Corporation, the Washington State Agricultural Research Center, and the National Rifle Association. We thank many students at Washington State University for contributing to this study. We especially thank M.L. Nelson for helpful comments with experimental design, R.A. Chapman for advice on developing equations, A.E. Hagerman for tannin assays, and L.A. Host who performed much of the statistical analysis. J.R. Nelson and B.B. Davitt served as co-principal investigators.

Mianuscript accepted 3 Jun. 1995. developed by Nelson et al. (1982), is highly correlated with dietary digestible energy in sheep and cattle (J.R. Nelson and B.B. Davitt, unpubl. data), but has not been tested with mule deer (Odocoileus hemionus hemionus Rafinesque) under controlled conditions.

To date, research with fecal indices has focused on domestic livestock (Holloway et al. 1981, Holechek et al. 1982, Wofford et al. 1985, Leite and Stuth 1990, Lyons and Stuth 1992, NunezHernandez et al. 1992). A few studies have been conducted with North American deer under controlled conditions (Short and Remmenga 1965, Mubanga et al. 1985, Howery and Pfister 1990). But, because of differences in diet selection, anatomy, and perhaps physiology, we cannot assume relationships for domestic ruminants will be the same for small cervids. Furthermore, our present knowledge of fecal index/diet quality relationships is based primarily on diets composed of only 1 to 4 species per diet, unlike the diverse diets selected by free-ranging ruminants. In this study, we examine relationships between fecal indices and diet quality using diverse mixtures of wild-grown forages.

Alternatives to the conventional dry matter basis of quantifying fecal indices also are examined. When wild ruminants consume soil at mineral licks (Weeks and Kirkpatrick 1976, Seip and Bunnell 1985), efficacy of dry matter-based fecal indices may be compromised. Ashing fecal samples and presenting data per unit organic matter appear to alleviate this problem (B.B. Davitt, pers. observ.). Also, Jenks et al. (1990) found fecal N, fecal neutral detergent fiber (NDF) and fecal acid detergent fiber (ADF) concentrations were not different after exposure for $<24$ days in Oklahoma. However, we believe weathering effects may exhibit regional and seasonal variability. Therefore, fecal index/diet quality relationships need to be examined for indices which might tolerate various pacific northwest conditions.

We investigated predictive relationships between diet quality/intake and corresponding fecal chemical constituents of black-tailed ( $O$. $h$. columbianus Richardson) and mule deer fed 1 single- and 10 mixed-species diets. We also examined the effect of quantifying fecal indices based on dry matter, organic matter, and neutral detergent fiber in feces on these relationships.

\section{Methods}

Diets were prepared from diverse mixtures of primarily wildgrown forages (Table 1); components were partially dried, 
Table 1. Percent composition of $10^{\mathrm{a}}$ mixed diets fed to black-tailed and mule deer for evaluating fecal indices, Washington State University, $1985-1987$.

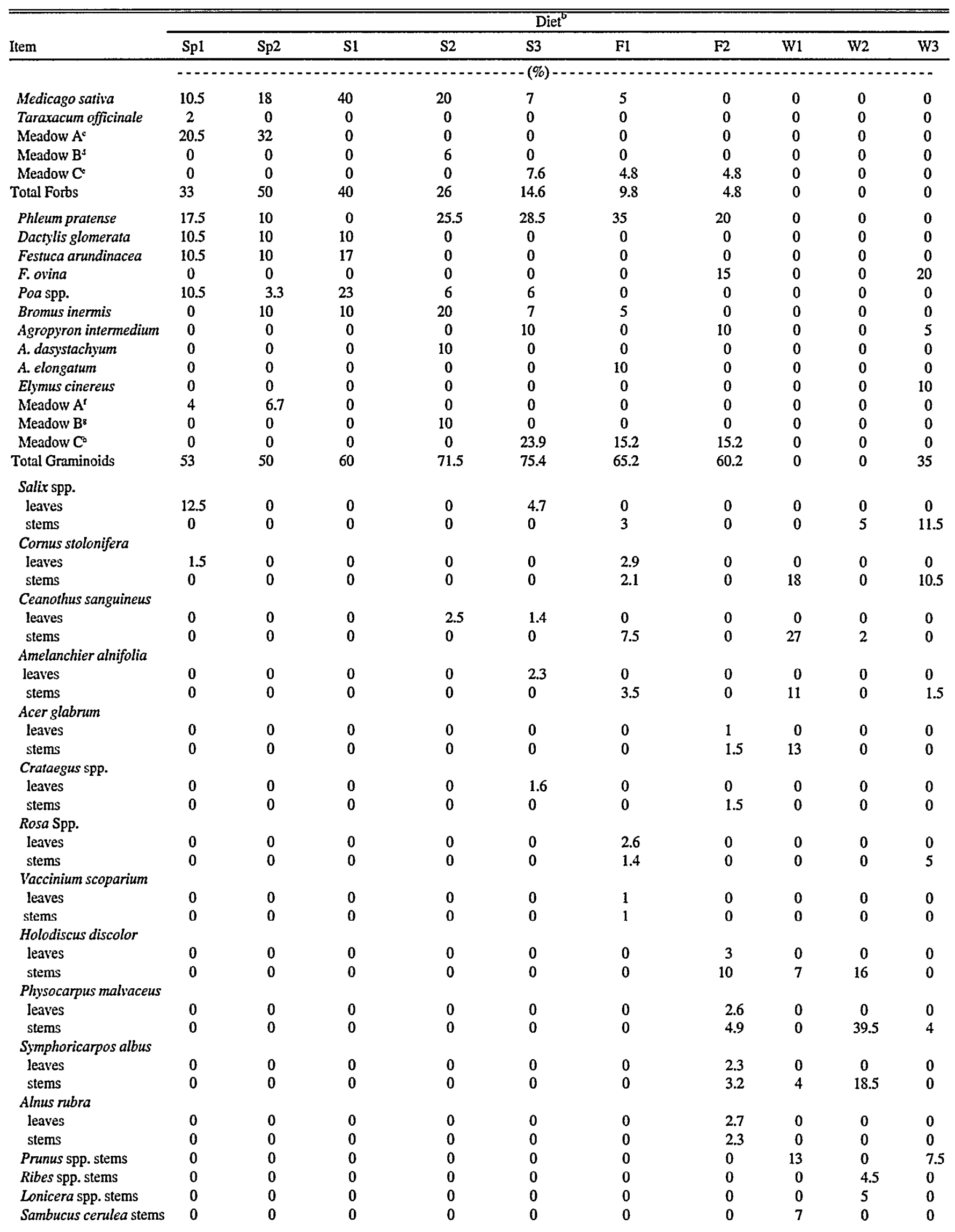


Table 1. Continued.

\begin{tabular}{|c|c|c|c|c|c|c|c|c|c|c|}
\hline \multirow[b]{2}{*}{ Item } & \multicolumn{10}{|c|}{ Diet $^{0}$} \\
\hline & Sp1 & $\mathrm{Sp} 2$ & Sl & \$2 & S3 & F1 & $\mathbf{F} 2$ & W1 & W2 & w3 \\
\hline & $-\ldots$ & & & $\cdots$ & $-(\%$ & $\ldots$ & $\ldots$ & $\ldots$ & $\ldots$ & $\ldots$ \\
\hline Pinus ponderosa & 0 & 0 & 0 & 0 & 0 & 0 & 0 & 0 & 4.25 & 7 \\
\hline Pseudotsuga menziesii & 0 & 0 & 0 & 0 & 0 & 0 & 0 & 0 & 5.25 & 7 \\
\hline Thuja plicata & 0 & 0 & 0 & 0 & 0 & 0 & 0 & 0 & 0 & 6 \\
\hline Total Decid. Leaves & 14 & 0 & 0 & 2.5 & 10 & 6.5 & 11.6 & 0 & 0 & 0 \\
\hline Total Decid. Stems & 0 & 0 & 0 & 0 & 0 & 18.5 & 23.4 & 100 & 90.5 & 40 \\
\hline Total Decid. Browse & 14 & 0 & 0 & 2.5 & 10 & 25 & 35 & 100 & 90.5 & 40 \\
\hline Total Conif. Browse & 0 & 0 & 0 & 0 & 0 & 0 & 0 & 0 & 9.5 & 20 \\
\hline Total Browse & 14 & 0 & 0 & 2.5 & 10 & 25 & 35 & 100 & 100 & 60 \\
\hline Total Arboreal Lichen' & 0 & 0 & 0 & 0 & 0 & 0 & 0 & 0 & 0 & 5 \\
\hline
\end{tabular}

An eleventh diet (Alf) comprised of 100 ç alfalfa hay also was fed.

Seasonal diets ( $\mathrm{Sp}=\mathrm{Spring}, \mathrm{S}=$ Summer, $\mathrm{F}=\mathrm{Fall}, \mathrm{W}=$ Winter $)$.

Collected 21 May 1986; includes $>13$ for species; Potentilla spp., Sisyrinchium angustifolium, Achillea millefolium, Camassia quamash, and Saxifraga spp. comprised $>70 \%$, many were in bloom.

${ }^{C}$ Collected 26 August 1985 ; includes $>6$ species of forbs, mostly Aster spp., Trifolium spp., Cirstum spp., and Achillea millefollum.

cCollected 4 October 1985; includes $>5$ species of forbs, mostly Aster spp., Trifolium spp., and Achillea millefolium.

Collected 21 May 1986; approximately $75 \%$ Poa spp. and 25\% Carex spp.

${ }_{5}$ Collected 26 August 1985; includes Phleum pratense, Dactylis glomerata, Poa spp., Bromus spp., and Carex spp.

Collected 4 Oetober 1985; includes $60 \%$ Phleum prasense, Poa spp., and Bromus spp., and 40\% Carex spp.

All browse was collected during fall and winter except for Salix spp. and Cornus stolonifera in diet Spl which were collected on 1 June 1986.

Lichen was mostly Alectoria fremontii, approximately $20 \%$ of diet by volume.

chopped, and thoroughly blended. Three black-tailed and 3 mule deer were used during the first 7 digestion trials; 5 mule deer were used in addition to the original 6 deer in various combinations during the final 4 trials. Each trial started with 6 animals (except diets Alf, W1, W2, and W3 which started with 7 deer), but on some diets (Table 2) we removed individual deer from trial conditions when their intake dropped precipitously. We housed deer within standard metabolism crates, and offered fresh feed and water ad libitum twice daily ( 0730 and 1700 hours); a mineral salt block also was provided. All deer received the same diet at the same time. Digestion trials consisted of a preliminary adjustment period ( $>13$ days) followed by a collection period (5-6 days). Length of collection periods was shortened for all individuals when any deer failed to maintain constant intake after 5 days. We collected orts (refused feed) and feces once per day
(1600 hours). Until chemical analyses could be performed, we stored subsamples of feed and orts at room temperature $\left(24^{\circ} \mathrm{C}\right)$ and feces at $-4^{\circ} \mathrm{C}$. Storage of feces indoors at room temperature in paper bags or quickly frozen or refrigerated in plastic bags stops bacterial growth. However, storage at room temperature in plastic bags for $>3$ days can elevate DAPA levels through continued microbial activity (B.B. Davitt, unpubl. data).

Samples of diet, orts, and feces were oven-dried at $55^{\circ} \mathrm{C}$, ground in a Wiley Mill to pass a $1.0 \mathrm{~mm}$ screen, and analyzed for crude protein and gross energy, using standard macro-Kjeldahl and bomb calorimetry (Parr adiabatic calorimeter) procedures, respectively (AOAC 1984). We determined fecal NDF and fecal ADF following methods of Mould and Robbins (1981a). We quantified fecal acid detergent lignin (ADL) according to Goering and Van Soest (1970) on the residual fecal ADF, but

Table 2. Body weights of deer and intake, crude protein content, and digestibility ${ }^{1}$ of 11 diets from in vivo digestion trials with black-tailed and mule deer, Washington State University, 1985-1987.

\begin{tabular}{|c|c|c|c|c|c|c|c|}
\hline Diet $^{2}$ & $\begin{array}{c}\text { Mean } \\
\text { body } \\
\text { weight }^{3}\end{array}$ & $\begin{array}{l}\text { Dry } \\
\text { matter } \\
\text { intake }\end{array}$ & $\begin{array}{l}\text { Digestible } \\
\text { crude } \\
\text { protein } \\
\text { intake }\end{array}$ & $\begin{array}{l}\text { Digestible } \\
\text { energy } \\
\text { intake }\end{array}$ & $\begin{array}{l}\text { Crude } \\
\text { protein }\end{array}$ & $\begin{array}{c}\text { Crude } \\
\text { protein } \\
\text { digestibility }\end{array}$ & $\begin{array}{c}\text { Energy } \\
\text { digestibility }\end{array}$ \\
\hline & $-(\mathrm{kg})-$ & \multicolumn{2}{|c|}{ - - -(g/kg body weight/day) - - - } & (kcals/kg bw/day) & \multicolumn{3}{|c|}{ 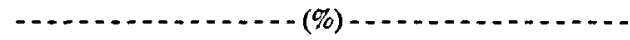 } \\
\hline Spl & $52.65(5)$ & $27.84 \pm 1.08$ & $3.50 \pm 0.19$ & $84.49 \pm 3.74$ & $18.52 \pm 0.08$ & $67.79 \pm 1.69$ & $68.32 \pm 1.06$ \\
\hline $\mathrm{Sp} 2$ & $54.34(5)$ & $27.67 \pm 1.53$ & $3.53 \pm 0.20$ & $82.44 \pm 3.94$ & $18.66 \pm 0.20$ & $67.86 \pm 0.83$ & $67.30 \pm 0.77$ \\
\hline Alf & $61.97(7)$ & $18.49 \pm 0.54$ & $2.33 \pm 0.10$ & $48.62 \pm 1.81$ & $17.44 \pm 0.37$ & $72.79 \pm 0.95$ & $58.53 \pm 0.86$ \\
\hline S1 & $74.59(6)$ & $19.03 \pm 1.48$ & $1.89 \pm 0.23$ & $50.11 \pm 3.99$ & $14.48 \pm 0.55$ & $67.15 \pm 1.17$ & $59.88 \pm 0.78$ \\
\hline $\mathbf{S 2}$ & $66.38(6)$ & $11.76 \pm 1.32$ & $0.81 \pm 0.10$ & $26.86 \pm 2.87$ & $12.70 \pm 0.35$ & $53.29 \pm 1.58$ & $51.63 \pm 0.69$ \\
\hline S3 & $65.03(6)$ & $12.31 \pm 1.07$ & $0.55 \pm 0.06$ & $27.51 \pm 2.47$ & $10.12 \pm 0.41$ & $43.25 \pm 1.89$ & $50.28 \pm 0.70$ \\
\hline F1 & $63.45(6)$ & $12.54 \pm 1.16$ & $0.64 \pm 0.06$ & $26.63 \pm 1.98$ & $10.82 \pm 0.28$ & $47.26 \pm 2.33$ & $47.44 \pm 0.58$ \\
\hline $\mathbf{F} 2$ & $61.28(6)$ & $12.05 \pm 1.47$ & $0.29 \pm 0.04$ & $23.22 \pm 2.31$ & $8.02 \pm 0.18$ & $29.55 \pm 1.28$ & $43.40 \pm 1.26$ \\
\hline W1 & $54.45(5)$ & $10.25 \pm 1.16$ & $0.10 \pm 0.02$ & $18.24 \pm 1.67$ & $6.63 \pm 0.21$ & $15.14 \pm 3.27$ & $36.05 \pm 1.84$ \\
\hline W2 & $51.75(2)$ & $9.72 \pm 1.14$ & $0.13 \pm 0.00$ & $16.86 \pm 1.36$ & $5.98 \pm 0.02$ & $19.60 \pm 1.16$ & $36.13 \pm 1.36$ \\
\hline W3 & $52.09(6)$ & $20.06 \pm 1.25$ & $0.51 \pm 0.05$ & $45.25 \pm 2.85$ & $7.39 \pm 0.17$ & $34.84 \pm 2.41$ & $47.23 \pm 0.99$ \\
\hline
\end{tabular}

Mean \pm standard error

${ }^{2}$ Seasonal diets: $\mathrm{Sp}=\mathrm{Spring}, \mathrm{S}=$ Summer, $\mathrm{F}=$ Fall, $\mathrm{W}=$ Winter, Alf $=$ Alfalfa.

${ }^{3}$ Post-trial; parentheses indicate numbers of deer used on that trial. 
Table 3. Concentration (mean \pm standard error) of nitrogen ${ }^{1}$ and 2,6-diaminopimelic acid ${ }^{2}$ in the feces of black-tailed and mule deer from 11 in vivo digestion trials, Washington State University, 1985-1987.

\begin{tabular}{|c|c|c|c|c|c|c|}
\hline \multirow[b]{2}{*}{ Diet $^{3}$} & \multicolumn{2}{|c|}{ Dry Matter Basis } & \multicolumn{2}{|c|}{ Organic Matter Basis } & \multicolumn{2}{|c|}{ ndf Basis } \\
\hline & Nitrogen & DAPA & Nitrogen & DAPA & Nitrogen & DAPA \\
\hline & $(g / 100 g)$ & $(\mathrm{mg} / \mathrm{g})$ & $(g / 100 \mathrm{~g})$ & $(\mathrm{mg} / \mathrm{g})$ & $(g / 100 g)$ & $(\mathrm{mg} / \mathrm{g})$ \\
\hline Spl & $2.97 \pm 0.13$ & $1.14 \pm 0.05$ & $3.37 \pm 0.11$ & $1.30 \pm 0.04$ & $5.56 \pm 0.30$ & $2.14 \pm 0.12$ \\
\hline Sp2 & $2.95 \pm 0.10$ & $1.29 \pm 0.05$ & $3.25 \pm 0.12$ & $1.43 \pm 0.06$ & $5.54 \pm 0.27$ & $2.43 \pm 0.12$ \\
\hline Alf & $1.86 \pm 0.03$ & $0.82 \pm 0.02$ & $2.00 \pm 0.02$ & $0.88 \pm 0.02$ & $2.84 \pm 0.06$ & $1.25 \pm 0.02$ \\
\hline S1 & $1.88 \pm 0.03$ & $0.69 \pm 0.02$ & $2.11 \pm 0.04$ & $0.77 \pm 0.03$ & $3.24 \pm 0.07$ & $1.18 \pm 0.04$ \\
\hline F1 & $1.69 \pm 0.03$ & $0.62 \pm 0.02$ & $1.79 \pm 0.04$ & $0.66 \pm 0.02$ & $2.50 \pm 0.06$ & $0.92 \pm 0.02$ \\
\hline $\mathbf{F} 2$ & $1.59 \pm 0.02$ & $0.60 \pm 0.03$ & $1.67 \pm 0.03$ & $0.62 \pm 0.03$ & $2.29 \pm 0.05$ & $0.86 \pm 0.05$ \\
\hline W1 & $1.40 \pm 0.06$ & $0.41 \pm 0.02$ & $1.35 \pm 0.05$ & $0.40 \pm 0.18$ & $1.65 \pm 0.03$ & $0.49 \pm 0.02$ \\
\hline W2 & $1.21 \pm 0.00$ & $0.38 \pm 0.01$ & $1.15 \pm 0.00$ & $0.37 \pm 0.01$ & $1.38 \pm 0.01$ & $0.44 \pm 0.01$ \\
\hline W3 & $1.43 \pm 0.02$ & $0.55 \pm 0.02$ & $1.48 \pm 0.03$ & $0.56 \pm 0.02$ & $1.97 \pm 0.03$ & $0.75 \pm 0.02$ \\
\hline
\end{tabular}

$1 \mathrm{~g} / 100 \mathrm{~g}$ fecal dry matter, organic matter, or neutral detergent fiber.

$2 \mathrm{mg} / \mathrm{g}$ fecal dry matter, organic matter, or neutral detergent fiber.

${ }^{3}$ Seasonal diets: $\mathrm{Sp}=\mathrm{Spring}, \mathrm{S}=\mathrm{S}$ ummer, $\mathrm{F}=$ Fall, $\mathrm{W}=$ Winter, Alf $=$ Alfalfa.

omitted asbestos fiber. We also analyzed DAPA according to Davitt and Nelson (1984). We determined dry matter and organic matter by difference in weight before and after drying in a convection oven at $100^{\circ} \mathrm{C}$ overnight and after ignition in a muffle furnace at $500^{\circ} \mathrm{C}$ for 2 hours, respectively. We calculated apparent digestibility of crude protein and energy as the amount consumed less the amount excreted in feces; we presented the result as a percentage of amount consumed (Table 2). We quantified protein precipitating capacity of tannins in the 11 diets using blue, dye-labeled bovine serum albumin (BSA) (Hagerman and Robbins 1987).

We pooled diet and fecal data separately across animals by diet before analysis (Tables 2,3, and 4). This procedure simulates how fecal indices would be used in the field, where animal identity is unknown and during subsequent analyses individual variation is pooled. Furthermore, Jenks et al. (1989) reported that composited fecal samples provided improved cost effectiveness without compromising efficacy of the fecal $\mathrm{N}$ technique. We used least squares regression analyses (SAS 1982) to examine relation- ships between each fecal index (N, DAPA, NDF, ADF, and ADL) and dry matter intake, digestible energy, digestible energy intake, crude protein content, crude protein digestibility, and digestible crude protein intake. We expressed each fecal index per unit organic matter and per unit dry matter in feces; fecal $\mathbf{N}$ and DAPA also were quantified per unit neutral detergent fiber in feces. These 12 fecal indices (Tables 3 and 4) were used as independent variables in models to predict diet quality and intake.

To select the best fit equation for each comparison, we first plotted all fecal indices against all diet quality and intake variables. We examined plots of residuals to be sure we met statistical assumptions. To model these relationships, each dependent and independent variable underwent transformations selected from figures given by Hoerl (1954). The 6 transformations on the independent variable were: $X, \ln (X), X^{2},(X) \ln (X), 1 / X$, and $1 / \ln (X)$. The 2 transformations on the dependent variable were: $Y$ and $\ln (\mathrm{Y})$. We made comparisons between all possible combinations of each $\mathrm{X}$ and $\mathrm{Y}$ transformation. We protected against experiment wise Type I error using a Bonferroni-corrected rejec-

Table 4. Concentration ${ }^{1}$ (mean \pm standard error) of neutral detergent fiber (NDF), acid detergent fiber (ADF), and acid detergent lignin (ADL) in the feces of black-tailed and mule deer resulting from 11 in vivo digestion trials, Washington State University, 1985-1987.

\begin{tabular}{|c|c|c|c|c|c|c|}
\hline $\operatorname{Diet}^{3}$ & \multicolumn{3}{|c|}{ Dry Matter Basis } & \multicolumn{3}{|c|}{ Oroanic Matter Basis } \\
\hline & & & 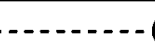 & - & 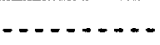 & - \\
\hline Spl & $53.67 \pm 1.72$ & $31.97 \pm 1.18$ & $11.56 \pm 0.55$ & $61.08 \pm 2.09$ & $36.45 \pm 1.79$ & $13.19 \pm 0.80$ \\
\hline Alf & $65.48 \pm 0.55$ & $47.21 \pm 0.70$ & $15.55 \pm 0.21$ & $70.73 \pm 0.89$ & $50.99 \pm 0.84$ & $16.79 \pm 0.14$ \\
\hline S1 & $58.19 \pm 0.52$ & $36.45 \pm 0.66$ & $7.84 \pm 0.32$ & $65.07 \pm 0.66$ & $40.74 \pm 0.62$ & $8.78 \pm 0.39$ \\
\hline S2 & $67.04 \pm 0.62$ & $43.52 \pm 0.92$ & $11.99 \pm 0.98$ & $70.75 \pm 0.55$ & $45.92 \pm 0.84$ & $12.64 \pm 0.99$ \\
\hline F1 & $67.75 \pm 0.56$ & $42.91 \pm 0.64$ & $12.73 \pm 0.42$ & $71.42 \pm 0.55$ & $45.24 \pm 0.72$ & $13.43 \pm 0.44$ \\
\hline $\mathrm{F} 2$ & $69.65 \pm 0.58$ & $47.11 \pm 0.20$ & $13.44 \pm 0.18$ & $72.90 \pm 0.39$ & $49.31 \pm 0.27$ & $14.07 \pm 0.20$ \\
\hline W1 & $84.65 \pm 0.41$ & $62.34 \pm 1.69$ & $25.46 \pm 0.47$ & $82.06 \pm 0.92$ & $60.42 \pm 1.67$ & $24.67 \pm 0.30$ \\
\hline W2 & $87.60 \pm 0.81$ & $60.40 \pm 1.20$ & $23.78 \pm 0.13$ & $83.86 \pm 0.78$ & $57.82 \pm 1.15$ & $22.77 \pm 0.13$ \\
\hline w3 & $72.66 \pm 0.86$ & $51.55 \pm 1.04$ & $18.46 \pm 0.58$ & $75.00 \pm 1.05$ & $53.22 \pm 1.24$ & $19.06 \pm 0.65$ \\
\hline
\end{tabular}

${ }_{2} / 100 \mathrm{~g}$ fecal dry matter or organic matter.

${ }^{2}$ Seasonal diets: $\mathrm{Sp}=$ Spring, $\mathrm{S}=$ Summer, $\mathrm{F}=$ Fall, $\mathrm{W}=$ Winter, Alf $=$ Alfalfa 
tion level, where alpha $=0.05$ with 72 independent tests (Beal and Khamis 1991). We used a fit index (Payandeh 1981) to compare precision of equations, because the coefficient of determination may not be used to compare equations with different dependent variable transformations. Fit indices, standard errors, and plots of the best models, were used to identify equations which best fit the data. When fecal indices accounted for $>80 \%$ of the variation in dependent variables, as indicated by the fit index, we were satisfied that corresponding equations were suitable for management purposes (Nunez-Hernandez et al. 1992).

\section{Results and Discussion}

\section{Dry Matter Intake}

Fecal diaminopimelic acid on a neutral detergent fiber basis exhibited the highest fit index and lowest standard error for any model (Table 5). All equations, except 5.9 - 5.12 using fecal ADF and fecal ADL, were significant $(P<0.05)$. Past studies with cattle (Holloway et al. 1981, Holechek et al. 1982, Wofford et al. 1985, Nunez-Hernandez et al. 1992) did not identify a fecal chemical constituent suitable for monitoring intake. However, forage intake among small ruminants may be more closely related to fecal indices of microbial origin. Deer have smaller rumen capacity and forage more selectively than larger ruminants (Short 1981). Nunez-Hernandez et al. (1992) found intake of goats on low phenolic diets was closely related to fecal N. Regardless of foraging strategy, forage intake may be difficult to model using only fecal chemistry because it is both a behavioral and biological phenomenon.

Table 5. Best fit (highest fit index and lowest standard error) of 12 fecal indices ${ }^{1}$ with dry matter intake ${ }^{2}$ (DMI) from digestion trials with black-tailed and mule deer, Washington State University, 1985-1987.

\begin{tabular}{|c|c|c|c|c|}
\hline No. & Equation $^{3}$ & $\begin{array}{c}\text { Fit } \\
\text { Index }\end{array}$ & $r^{2}$ & $S_{y . x}$ \\
\hline 1 & $\mathrm{DMI}=5.889+9.441$ (DAPAndf) & 0.804 & $0.782^{*}$ & 3.08 \\
\hline 5.2 & $\mathrm{DMI}=\exp (2.009+0.982(\mathrm{DAPAOm}))$ & 0.788 & $0.717^{*}$ & 3.21 \\
\hline 5.3 & $\mathrm{DMI}=\exp (-0.199+208.748(1 / \mathrm{FNDFom}))$ & 0.781 & $0.706^{*}$ & 3.26 \\
\hline 5.4 & $\mathrm{DMI}=10.108+1.851$ (FNndf) $\ln (\mathrm{FNndf})$ & 0.776 & $0.751^{*}$ & 3.30 \\
\hline 5.5 & $\mathrm{DMI}=\exp (0.714+135.696(1 / \mathrm{FND})$ & 0.771 & $0.692 *$ & 3.33 \\
\hline 56 & $\mathrm{DMI}=\exp (1.939+1.155$ & 0.770 & $0.706^{*}$ & 3.34 \\
\hline 5.7 & $\mathrm{DMI}=8.805+1.715$ & 0.758 & $0.731^{*}$ & 3.43 \\
\hline 5.8 & $\mathrm{DMI}=7.928+2.243(\mathrm{FNdm})^{2}$ & 0.744 & $0.716^{*}$ & 3.53 \\
\hline 5.9 & $D M I=\exp (1.445+57.111(1 / F$ & 0.721 & 0 & 3.68 \\
\hline 5.10 & $\mathrm{DMI}=\exp (1.175+73.524(1 / \mathrm{FADFom}))$ & 0.690 & 0.570 & 3.88 \\
\hline 5.11 & $\mathrm{DMI}=\exp (3.345-0.037$ (FADLdm) $)$ & 0.258 & 0.226 & 6.00 \\
\hline 5.12 & $\mathrm{DMII}=26.161-0.626$ (FADLom) & 0.218 & 0.132 & 6.16 \\
\hline
\end{tabular}

'Feeal 2,6 diaminopimelic acid (DAPA), nitrogen (FN), neutral detergent fiber (FNDF), acid detergent fiber (FADF), acid detergent lignin (FADL); organic matter basis (om), dry matter basis (dm), neutral detergent fiber basis (ndf).

$2 \mathrm{~g} / \mathrm{kg}$ body weight/day

${ }^{3}$ For equations using $\ln Y, r^{2}$ is based on transformed $y$-variable. $* P<0.05$

\section{Energy Digestibility and Intake}

Our best single index of digestible energy, as indicated by both the fit index and standard error, was fecal NDF on a dry matter basis (Table 6). All equations in table 6, except 6.11 and 6.12, described significant relationships $(P<0.05)$. Although Mubanga
Table 6. Best fit (highest fit index and lowest standard error) of 12 fecal indices ${ }^{1}$ with digestible energy ${ }^{2}$ (DE) from digestion trials with blacktailed and mule deer, Washington State University, 1985-1987.

\begin{tabular}{|c|c|c|c|c|}
\hline No. & Equa & $\begin{array}{c}\text { Fit } \\
\text { Index }\end{array}$ & $r^{2}$ & $S_{y . x}$ \\
\hline 6.1 & $\mathrm{DE}=\exp (9.521-1.331(\ln (\mathrm{FNDFdm})))$ & 0.938 & $0.931^{*}$ & 2.92 \\
\hline 6.2 & $\mathrm{DE}=51.667+20.334(\ln ($ DAPAndf $))$ & 0.933 & $0.925^{*}$ & 3.03 \\
\hline 6.3 & $\mathrm{DE}=60.408+25.314(\ln (\mathrm{DAPAOm}))$ & 0.919 & $0.910^{*}$ & 3.32 \\
\hline 6.4 & $\mathrm{DE}=27.335+24.349(\mathrm{ln}(\mathrm{FNndf}))$ & 0.918 & $0.909 *$ & 3.34 \\
\hline 6.5 & $\mathrm{DE}=\exp \left(4.906-0.00019(\mathrm{FNDFom})^{2}\right)$ & 0.916 & $0.909 *$ & 3.39 \\
\hline 6.6 & $\mathrm{DE}=\exp (4.516-0.372(1 / \mathrm{DAPAdm}))$ & 0.908 & $0.899 *$ & 3.55 \\
\hline 6.7 & $\mathrm{DE}=30.759+32.015(\mathrm{In}(\mathrm{FN}$ & 0.904 & $0.893^{*}$ & 3.63 \\
\hline 6.8 & $\mathrm{DE}=91.518-69.924(1 / \mathrm{FNdm})$ & 0.881 & $0.868^{*}$ & 4.03 \\
\hline 6.9 & $\mathrm{DE}=\exp (4.83-0.02(\mathrm{FAD}$ & 0.859 & $0.847^{*}$ & 4.38 \\
\hline 6.10 & $\mathrm{DE}=\exp \left(4.512-0.00025(\text { FADFom })^{2}\right)$ & 0.804 & $0.784^{*}$ & 5.17 \\
\hline 6.11 & $\mathrm{DE}=\exp (4.404-0.032($ FADLdm $))$ & 0.613 & 0.638 & 7.27 \\
\hline 6.12 & $\mathrm{DE}=70.379-0.441$ (FADLom)ln(FADLom) & 0.561 & 0.512 & 7.74 \\
\hline
\end{tabular}

${ }^{\mathrm{T}}$ Fecal 2,6 diaminopimelic acid (DAPA), nitrogen (FN), neutral detergent fiber (FNDF), acid detergent fiber (FADF), acid detergent lignin (FADL); organic matter basis (om), dry matter basis (dm), neutral detergent fiber basis (ndf).

3 Percent

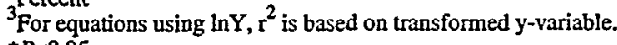
$* P<0.05$

et al. (1985) found only weak relationships between fecal NDF and diet digestibility, Short and Remmenga (1965) found fecal cellulose (not examined in our study) was a reliable index of digestible energy in deer. They concluded cellulose was the primary cell wall constituent influencing the digestibility of energy. Furthermore, during neutral detergent analysis, microbial and other endogenous matter are removed rather than plant cell contents. These solubles should contain most of the microbial debris in feces, including fecal $\mathrm{N}$ and DAPA. The complementary relationship between fecal NDF and neutral detergent solubles (i.e., 100-\%fecal NDF) during neutral detergent analysis probably contributes to the usefulness of fecal NDF. Thus, fecal NDF should give results similar to fecal $\mathrm{N}$ and DAPA. When sequentially determined, fecal ADF and ADL would be more distantly related to this endogenous material because of previous solubilization, resulting in their poorer predictive capabilities.

Fecal diaminopimelic acid (ndf basis) provided the most precise estimate of digestible energy intake (Table 7). Only equations 7.11 and 7.12 were not significant $(P<0.05)$. However, Leite and Stuth (1990) found concentration of insoluble $N$ in the feces of steers was most closely correlated with digestible energy intake, but not with sufficient precision for predictive use. In our study, DAPA, fecal NDF, and fecal $\mathrm{N}$ were good indices of digestible energy intake. Fecal $\mathrm{N}$ is largely of microbial origin $(>70 \%)$, where microbial $\mathrm{N}$ in the feces closely corresponds to the level of energy metabolism of the ruminant host (Mason 1969). Weller (1969) reported $80 \%$ of the ruminant's energy is derived from volatile fatty acids produced by rumen bacteria. Diaminopimelic acid is found almost exclusively in bacterial cell walls (Work and Dewey 1953, Purser and Buechler 1966) except for in a few blue-green algae (Work and Dewey 1953). Although small amounts have been isolated from common foodstuffs (e.g. silage and hay) (Czerkawski 1974, Dufva et al. 1982), the presence of DAPA in hay and silage has been attributed to bacterial contamination (Dufva et al. 1982). Therefore, DAPA should provide a more specialized indication of microbial dynamics than fecal N. Further, low levels of digestible energy in the diet may limit microbial growth and should be detected by decreases in DAPA. However, degradation of DAPA by hindgut microbes has 
Table 7. Best fit (highest fit index and lowest standard error) of 12 fecal indices ${ }^{1}$ with digestible energy intake ${ }^{2}$ (DED) from digestion trials with black-tailed and mule deer, Washington State University, 1985-1987.

\begin{tabular}{|c|c|c|c|c|}
\hline No. & Equation $^{3}$ & $\begin{array}{c}\text { Fit } \\
\text { Index }\end{array}$ & $\mathbf{r}^{2}$ & $S_{y . x}$ \\
\hline 7.1 & $\mathrm{DEI}=0.584+35.831$ (DAPAndf) & 0.877 & $0.863^{*}$ & 8.90 \\
\hline 7.2 & $\mathrm{DEI}=\exp (4.022+1.199(\ln ($ DAPAom $)))$ & 0.865 & $0.785^{*}$ & 9.29 \\
\hline 7.3 & $\mathrm{DEI}=\exp (0.415+211.317(1 / \mathrm{FNDFdm}))$ & 0.863 & $0.785 *$ & 9.36 \\
\hline 7.4 & $\mathrm{DEI}=16.398+7.083$ (FNndf)In(FNndf) & 0.860 & $0.844^{*}$ & 9.49 \\
\hline 7.5 & $\mathrm{DEI}=\exp (4.153+1.353(\ln (\mathrm{DAPAdm})))$ & 0.854 & $0.783^{*}$ & 9.68 \\
\hline 7.6 & $\mathrm{DEI}=\exp (-0.963+322.086(1 / \mathrm{FNDFom}))$ & 0.849 & $0.784^{*}$ & 9.85 \\
\hline 7.7 & $\mathrm{DEI}=11.327+6.58(\mathrm{FNom})^{2}$ & 0.845 & $0.828^{*}$ & 9.97 \\
\hline 7.8 & $\mathrm{DEI}=7.935+8.615(\mathrm{FNdm})^{2}$ & 0.831 & $0.812^{*}$ & 10.42 \\
\hline 7.9 & $\mathrm{DEI}=\exp (1.564+88.729(1 / \mathrm{FADFdm}))$ & 0.811 & $0.689 *$ & 11.01 \\
\hline 7.10 & $\mathrm{DEI}=\exp (1.159+113.685(1 / \mathrm{FADFom}))$ & 0.766 & $0.638^{*}$ & 12.25 \\
\hline 7.11 & $\mathrm{DEI}=\exp (4.598-0.063(\mathrm{FADLdm}))$ & 0.302 & 0.324 & 21.15 \\
\hline .12 & $\mathrm{DEI}=78.888-2.463$ (FADLom) & 0.256 & 0.174 & 21.84 \\
\hline
\end{tabular}

Fecal 2,6 diaminopimelic acid (DAPA), nitrogen (FN), neutral detergent fiber (FNDF), acid detergent fiber (FADF), acid detergent lignin (FADL); organic matter basis (om), dry matter basis (dm), neutral detergent fiber basis (ndf).

kcals/kg body weight/day

${ }^{3}$ For equations using $\ln Y, r^{2}$ is based on transformed $y$-variable.

${ }^{*} P<0.05$

been observed (Mason and White 1971). Extent of breakdown may depend at least in part on type of feed (Orskov et al. 1970) and perhaps on composition of the microbial community.

\section{Crude Protein Content, Digestibility, and Intake}

The best single predictor of crude protein in our experimental diets was fecal N (ndf basis) (Table 8); all 3 DAPA indices also were suitable predictors. Mubanga et al. (1985) also found a close relationship between diet $\mathrm{N}$ and fecal $\mathrm{N}$ for mule deer and concluded fecal $\mathrm{N}$ was potentially valuable for monitoring fluctuations in diet quality. Howery and Pfister (1990) found that under controlled conditions fecal $\mathrm{N}$ was useful for detecting large differences in diet $\mathrm{N}$.

Table 8. Best fit (highest fit index and lowest standard error) of 12 fecal indices ${ }^{1}$ with crude protein content ${ }^{2}$ (CP) from digestion trials with black-tailed and mule decr, Washington State University, 1985-1987.

\begin{tabular}{|c|c|c|c|c|}
\hline No. & Equation $^{3}$ & $\begin{array}{c}\text { Fit } \\
\text { Index }\end{array}$ & $\mathrm{r}^{2}$ & $s_{y \cdot x}$ \\
\hline 8.1 & $C P=\exp (3.360-2.356(1 / F N n d f))$ & 0.848 & $0.845^{*}$ & 1.97 \\
\hline 8.2 & $\mathrm{CP}=11.968+8.375(\mathrm{ln}(\mathrm{DAPAndf}))$ & 0.845 & $0.828^{*}$ & 1.99 \\
\hline 8.3 & $\mathrm{CP}=\exp (3.5-0.68(1 / \mathrm{DAPAdm}))$ & 0.845 & $0.820^{*}$ & 1.99 \\
\hline 8.4 & $\mathrm{CP}=15.587+10.480(\ln ($ DAPAom $))$ & 0.842 & $0.824 *$ & 2.01 \\
\hline 8.5 & $\mathrm{CP}=28.810-29.548(1 / \mathrm{FNdm})$ & 0.840 & $0.823^{*}$ & 2.02 \\
\hline 8.6 & $\mathrm{CP}=3.253+13.346(\ln (\mathrm{FNom}))$ & 0.839 & $0.821^{*}$ & 2.03 \\
\hline 8.7 & $\mathrm{CP}=-15.38+1809.655(1 / \mathrm{FNDFdm})$ & 0.807 & $0.786^{*}$ & 2.22 \\
\hline 8.8 & $C P=\exp \left(4.194-0.00035(\text { FNDFom })^{2}\right)$ & 0.796 & $0.804 *$ & 2.29 \\
\hline 8.9 & $\mathrm{CP}=-55.034+252.87(1 / \mathrm{n}(\mathrm{FADFdm}))$ & 0.726 & 0.696 & 2.64 \\
\hline 8.10 & $\mathrm{CP}=\exp \left(3.478-0.00045(\mathrm{FADFom})^{2}\right)$ & 0.680 & 0.680 & 2.86 \\
\hline 8.11 & $\mathrm{CP}=\exp (3.289-0.058(\mathrm{FADLdm}))$ & 0.481 & 0.547 & 3.64 \\
\hline 8.12 & $\mathrm{CP}=19.124-0.169$ (FADLom)ln(FADLom) & 0.439 & 0.376 & 3.79 \\
\hline
\end{tabular}

Fecal 2,6 diaminopimelic acid (DAPA), nitrogen (FN), neutral detergent fiber (FNDF), acid detergent fiber (FADF), acid detergent lignin (FADL); organic matter basis (om), dry matter basis (dm), neutral detergent fiber basis (ndf).

${ }_{3}^{2}$ Percent

${ }^{3}$ For equations using $\ln \mathrm{Y}, \mathrm{r}^{2}$ is based on transformed $y$-variable.

$* P<0.05$
Unlike crude protein content, the best index of crude protein digestibility was DAPA on a neutral detergent fiber basis (Table 9) and DAPA on an organic matter basis was the best for digestible crude protein intake (Table 10). Clearly, DAPA (ndf basis) is the best overall estimator for all 3 crude protein variables. Fecal indices of microbial origin again provided the greatest precision. Only slight differences were evident between equations 9.1, 9.2, 9.3, and 9.4, in either fit index or $\mathrm{r}^{2}$. However, with the relatively low fit indices and high standard errors for equations predicting crude protein digestibility, we feel these do not offer predictive capability.

\section{Tannins}

The most limiting factor in using fluctuations in fecal $\mathrm{N}$ to indicate changes in diet quality is the presence of protein-complexing tannins. Holechek et al. (1982) and Leslie and Starkey (1985), examining data of Mould and Robbins (1981b), noted that hightannin forages must comprise approximately 25 to $33 \%$ of the diet before the fecal N/diet $\mathrm{N}$ relationship was affected. Our protein precipitation assays revealed only 5 of our 11 diets contained measurable amounts of tannins and 2 of the tannin-containing diets (S2 and S3) precipitated only trace amounts of BSA. Extracts from diets W1, W2, and W3 precipitated 0.136, 0.031, and $0.300 \mathrm{mg} \mathrm{BSA} / \mathrm{mg}$ forage, respectively. In comparison, McArthur et al. (1993) reported protein precipitation (mg BSA/g forage) from leaves of blueberry (Vaccinium spp. L.) ranging from 0.08-0.17, red stem ceanothus (Ceanothus sanguineus Pursh) at 0.12 , mountain maple (Acer glabrum Torr.) at 0.41 , red osier dogwood (Cornus stolonifera Michx.) at 0.51, and fireweed (Epilobium angustifolium L.) from 0.50 to 0.84 . Tannins in our diets precipitated only low to moderate amounts of protein and likely did not reduce protein digestibility. The tannin:protein ratio in consumed forages may be important in determining whether insoluble tannin/protein complexes will form (Hagerman and Robbins 1987). Perhaps, our diets were either too low in tannins or too high in protein to affect our diet quality and intake predictions. Further, saponins in some forages (not measured during our

Table 9. Best fit (highest fit index and lowest standard error) of 12 fecal indices ${ }^{1}$ with digestible crude protein ${ }^{2}$ (DCP) from digestion trials with black-tailed and mule deer, Washington State University, 1985-1987.

\begin{tabular}{|c|c|c|c|c|}
\hline No. & Equation ${ }^{3}$ & $\begin{array}{c}\text { Fit } \\
\text { Index }\end{array}$ & $r^{2}$ & $s_{y . x}$ \\
\hline 9.1 & $\mathrm{DCP}=\exp (4.719-0.838(1 / \mathrm{DAPAndf}))$ & 0.785 & $0.832 *$ & 10.00 \\
\hline 9.2 & $\mathrm{DCP}=131.927-0.016(\mathrm{FNDFom})^{2}$ & 0.785 & $0.761^{*}$ & 10.00 \\
\hline 9.3 & $\mathrm{DCP}=91.356-109.942(1 / \mathrm{FNndf})$ & 0.785 & $0.761^{*}$ & 10.01 \\
\hline 9.4 & $\mathrm{DCP}=98.384-32.093(1 / \mathrm{DAPAdm})$ & 0.782 & $0.758 *$ & 10.07 \\
\hline 9.5 & $D C P=\exp \left(5.263-0.00032(F N D F d m)^{2}\right)$ & 0.773 & $0.838 *$ & 10.27 \\
\hline 9.6 & $\mathrm{DCP}=104.769-105.105(1 / \mathrm{FNom})$ & 0.765 & $0.739 *$ & 10.45 \\
\hline 9.7 & $\mathrm{DCP}=\exp (4.951-0.769(1 / \mathrm{DAPAom}))$ & 0.736 & 0.812 & 11.07 \\
\hline 9.8 & $\mathrm{DCP}=113.979-116.789(1 / \mathrm{FNdm})$ & 0.722 & 0.691 & 11.37 \\
\hline 9.9 & $\mathrm{DCP}=97.304-0.022$ (FADFom $^{2}$ & 0.679 & 0.644 & 12.21 \\
\hline 9.10 & $\mathrm{DCP}=\exp \left(4.855-0.00050(\mathrm{FADFdm})^{2}\right)$ & 0.676 & 0.800 & 12.28 \\
\hline 9.11 & $\mathrm{DCP}=\exp \left(4.375-0.0024(\mathrm{FADLdm})^{2}\right)$ & 0.624 & 0.745 & 13.22 \\
\hline 9.12 & $\mathrm{DCP}=\exp \left(4.478-0.0027(\mathrm{FADLom})^{2}\right)$ & 0.563 & 0.701 & 14.26 \\
\hline
\end{tabular}

Fecal 2,6 diaminopimelic acid (DAPA), nitrogen (FN), neutral detergent fiber (FNDF), acid detergent fiber (FADF), acid detergent lignin (FADL); organic matter basis (om), dry matter basis (dm), neutral detergent fiber basis (ndf).

${ }^{2}$ Percent

${ }^{3}$ For equations using $\ln Y, r^{2}$ is based on transformed $y$-variable. 
Table 10. Best fit (highest fit index and lowest standard error) of 12 fecal indices ${ }^{1}$ with digestible crude protein intake ${ }^{2}$ (DCPI) from digestion trials with black-tailed and mule deer, Washington State University, 1985-1987.

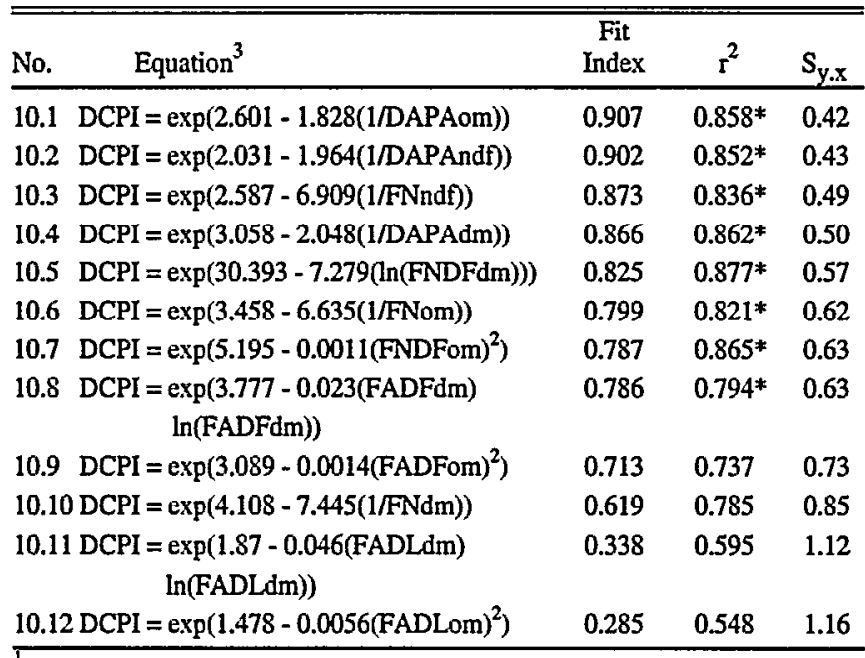

Fecal 2,6 diaminopimelic acid (DAPA), nitrogen (FN), neutral detergent fiber (FNDF), acid detergent fiber (FADF), acid detergent lignin (FADL); organic mauter basis (om), dry matter basis (dm), neutral detergent fiber basis (ndf).

gekg body weightday

'For equations using $\ln \mathrm{Y}, \mathrm{r}^{2}$ is based on transformed $\mathrm{y}$-variable.

$* P<0.05$

study) also may reduce toxic effects of tannins (Freeland et al. 1985). Presumably, free-ranging deer might consume combinations of forages which minimize noxious effects. Regardless of these findings, deer managers using fecal $\mathrm{N}$ to monitor diet quality and intake need to know which forages are high in tannins and how important these forages are in the diet of deer in their area. Because tannin-protein complexes are excreted in feces, presumably without benefit to rumen microbes, DAPA and fecal NDF should be more sensitive to fluctuations in diet quality than fecal $\mathrm{N}$, especially when diets are comprised of significant amounts of tannin-containing forages.

\section{Alternative Methods of Quantification}

In general, quantifying fecal NDF on a dry matter basis and DAPA and fecal $\mathrm{N}$ on a neutral detergent fiber basis resulted in the most precise equations for predicting diet quality and intake. Dry matter is the simplest and least labor-intensive method of quantifying fecal indices. Predictive equations using fecal indices quantified on an organic matter basis performed similarly to those on a dry matter basis. Differences between fiber indices when quantified by dry matter and organic matter may result from partial solubility of some of the total ash fraction (used to correct for organic matter) in neutral detergent solution. Presenting data per unit organic matter, however, has advantages over the dry matter basis because inadvertent ingestion of soil while grazing, although minor in wild ungulates (Beyer et al. 1994), could reduce the amount of fecal constituent per unit dry matter, but should have no affect on the amount per unit organic matter. Furthermore, some range ruminants intentionally consume large amounts of soil from mineral licks, particularly during spring and early summer (Weeks and Kirkpatrick 1976, Seip and Bunnell 1985). When ruminants are using mineral licks, quantifying fecal indices on a dry matter basis may lead to underestimates of diet quality and intake.
We speculate that deer feces collected from melting snow or from damp forest litter might appear fresh, yet have lost some soluble organic material because of exposure. Under these conditions, we believe the undigested cell wall constituents in feces are least likely to be solubilized and would therefore provide a more suitable method of quantifying fecal indices. Quantifying fecal $\mathrm{N}$ and DAPA per unit neutral detergent fiber in feces is superior to both the organic matter and dry matter basis under controlled conditions, however, exposure tests of ndf-based indices are still needed in a variety of climates and seasons. Furthermore, because we found fecal NDF to be a suitable index of deer diet quality and intake by itself, coupling it with fecal $\mathrm{N}$ and DAPA reduces some of the variability associated with fecal organic matter or dry matter output; the result is a superior single index which may have added potential for overcoming biases in the field.

\section{Limitations and Implications}

Our basic criteria for whether or not an equation should be used for management purposes (i.e., independent variable accounts for $80 \%$ of variation in dependent variable) follows NunezHernandez et al. (1992) in a similar study. However, managers must exercise caution with some of our equations. Many equations describe complex curvilinear relationships. Furthermore, data outside the range that was used to develop these relationships should not be used to predict diet quality and intake.

In contrast to findings with domestic ruminants, some fecal indices are closely related to diet quality and intake in blacktailed and mule deer. Perhaps the wide variation in forage species and forage quality consumed by deer over the course of a year may make fecal indices more appropriate as deer tend to feed more selectively (Short 1981) than other range ruminants. Most of our data probably encompass the low range of diet quality for free-ranging deer, but because overwinter mortality is related to animal condition prior to winter (Mautz 1978) and not simply quality of winter forage, we also included high quality diets in our relationships. Although these markedly different diets are likely to be consumed by deer over a year, using such a wide range of diet quality may have improved the fit of our equations. Furthermore, in our modeling of fecal indices, we pooled individual animal variation in an attempt to mimic field application of this technique and this too probably improved the fit of our equations. We also found that curvilinear models best described the relationships between fecal indices and diet quality. Simple linear regressions rarely provided the best fit equation.

\section{Conclusions}

Deer managers can monitor trends in black-tailed and mule deer diet quality and intake using DAPA, fecal NDF, and fecal N using predictive equations. Of our 11 diets, only 3 contained low to moderate amounts of protein precipitating tannins; thus, we were unable to evaluate the effects of tannins on the efficacy of fecal indices. However, using different methods to quantify fecal indices affected the precision of predictive equations. Indices of microbial origin (fecal N and DAPA) were most precise when presented on a fecal ndf basis rather than organic matter or dry matter; fiber indices were often most precise when based on fecal dry matter rather than organic matter. Ingestion of soil could bias results of dry matter-based indices. Data on effects of weathering 
especially in moist climates is needed to test the validity of ndfbased indices, but, DAPA and fecal N, when quantified on a neutral detergent fiber basis, appear to have potential outside these conditions given their overall performance. Fecal indices, along with a knowledge of herd food habits (Nunez-Hernandez et al. 1992) shuuld allow free-ranging black-tailed and mule deer to be managed based on the quality of habitat available to them.

\section{Literature Cited}

A. O. A. C. 1984. Official methods of analysis of official analytical chemists. Assoc. Off. Analy. Chem. Arlington, Virg.

Beal, K.G. and H.J. Khamis. 1991. A problem in statistical analysis: simultaneous inference. Condor 93:1023-1025.

Beier, P. 1987. Sex differences in quality of white-tailed deer diets. J. Mammal. 68:323-329.

Beyer, W.N., E.E. Connor, and S. Gerould. 1994. Estimates of soil ingestion by wildlife. J. Wildl. Manage. 58:375-382.

Czerkawski, J.W. 1974. Methods for determining 2-6-diaminopimelic acid and 2-aminoethylphosphonic acid in gut contents. J. Sci. Food Agr. 25:45-55.

Davitt, B.B. and J.R. Nelson. 1984. Methodology for the determination of DAPA in feces of large ruminants, p. 133-147. In: R.W. Nelson (ed.), Proc. West. States and Prov. Elk Workshop Edmonton, Alb.

Dufva, G.S., E.E. Bartley, M.J.Arambel, T.G. Nagaraja, S.M. Dennis, S.J. Galitzer, and A.D. Dayton. 1982. Diaminopimelic acid content of feeds and rumen bacteria and its usefulness as a rumen bacterial marker. J. Dairy Sci. 65:1754-1759.

Freeland, W.J., P.H. Calcott, and L.R. Anderson. 1985. Tannins and saponin: interaction in herbivore diets. Biochem. Syst. Ecol. 13:189-193.

Goering, H.K. and P.J. Van Soest. 1970. Forage analyses (apparatus, reagents, procedures, and some applications). USDA, Agr. Handb. 379.

Hagerman, A.E. and C.T. Robbins. 1987. Implications of soluble tannin-protein complexes for tannin analysis and plant defense mechanisms. J. Chem. Ecol. 13:1243-1259.

Hodgman, T.P. and R.T. Bokyer. 1986. Fecal crude protein relative to browsing intensity by white-tailed deer on wintering areas in Maine. Acta Theriol. 31:347-353.

Hoerl, A.E., Jr. 1954. Fitting curves to data, p. 20.55-20.77. In: J.H. Perry (ed.), Chemical Business Handbook. 1st ed. McGraw-Hill Book Co., New York, N.Y.

Holechek, J.L., M. Vavra, and D. Arthun. 1982. Relationships between performance, intake, diet nutritive quality and fecal nutritive quality of cattle on mountain range. J. Range Manage. 35:741-744.

Holloway, J.W., R.E. Estell, and W.T. Butts, Jr. 1981. Relationship between fecal components and forage consumption and digestibility. J. Anim. Sci. 52:836-848.

Howery, L.D. and J.A. Pfister. 1990. Dietary and fecal concentrations of nitrogen and phosphorous in penned white-tailed deer does. $\mathrm{J}$. Wildlife Manage. 54:383-389.

Jenks, J.A., D.M. Leslie, Jr., R.L. Lochmiller, M.A. Melchiors, and W.D. Warde. 1989. Effect of compositing samples on analysis of fecal nitrogen. J. Wildl. Manage. 53:213-215.

Jenks, J.A., R.B. Soper, R.L. Lochmiller, and D.M. Leslie, Jr. 1990. Effect of exposure on nitrogen and fiber characteristics of white-tailed deer feces. J. Wildl. Manage. 54:389-391.

Kie, J.G. and T.S. Burton. 1984. Dietary quality, fecal nitrogen and 2,6 diaminopimelic acid in black-tailed deer in northern California. USDA Forest Serv., Res. Note PSW-364 Berkeley, Calif.

Leite, E.R. and J.W. Stuth. 1990. Value of multiple fecal indices for predicting diet quality and intake of steers. J. Range Manage. 43:139-143.

Leslie, D.M. and E.E. Starkey. 1985. Fecal indices to dietary quality of cervids in old-growth forests. J. Wildl. Manage. 49:142-146.
Leslie, D.M., J.A. Jenks, M. Chilelli, and G.R. Lavigne. 1989. Nitrogen and diaminopimelic acid in deer and moose feces. J. Wildl. Manage. 53:216-218.

Lyons, R.K. and J.W. Stuth. 1992. Fecal NIRS equations for predicting diet quality of free-ranging cattle. J. Range Manage. 45:238-244.

Mason, V.C. 1969. Somc observations on the distribution and origin of nitrogen in sheep feces. J. Agr. Sci. 73:99-111.

Mason, V.C. and F. White. 1971. The digestion of bacterial mucopeptide constituents in the sheep. 1. the metabolism of 2,6-diaminopimelic acid. J. Agr. Sci. 77:91-98.

Mautz, W. W. 1978. Sledding on a brushy hillside: the body fat cycle in deer. Wildl. Soc. Bull. 6:88-90.

McArthur, C., C.T. Robbins, A.E. Hagerman, and T.A. Hanley. 1993. Diet selection by a ruminant generalist browser in relation to plant chemistry. Can. J. Zool. 71:2236-2243.

Mould, E.D. and C.T. Robbins. 1981a. Evaluation of detergent analysis in estimating nutritional value of browse. J. Wildl. Manage. 45:937-947.

Mould, E.D. and C.T. Robbins. 1981b. Nitrogen metabolism in elk. J. Wildl. Manage. 45:323-334.

Mubanga, G., J.L. Holechek, R. Valdez, and S.D. Schemnitz. 1985. Relationships between diet and fecal nutritive quality in mule deer. Southwest. Nat. 30:573-578.

Nelson, J.R., R.M. Koes, W.H. Miller, and B.B. Davitt. 1982. Big game habitat management on a nutritional basis-a new approach, $p$. 157-166. In: T.L. Britt, and D.P. Theobald (eds.), Proc. West. States and Prov. Elk Workshop, Flagstaff, Ariz.

Nunez-Hernandez, G., J.L. Holechek, D. Arthun, A. Tembo, J.D. Wallace, M.L. Galyean, M. Cardenas, and R. Valdez. 1992. Evaluation of fecal indicators for assessing energy and nitrogen status of cattle and goats. J. Range Manage. 45:143-147.

Orskov, E.R., C. Fraser, V.C. Mason, and S.O. Mann. 1970. Influence of starch digestion in the intestine of sheep on caecal fermentation, caecal microflora, and fecal nitrogen excretion. Brit. J. Nutr. 24:671-682.

Payandeh, B. 1981. Choosing regression models for biomass prediction equations. Forest. Chron. 57:229-232.

Purser, D.B. and S.M. Buechler. 1966. Amino acid composition of rumen organisms. J. Dairy Sci. 49:81-84.

SAS. 1982. SAS user's guide; statistics, 1982 Ed. SAS Inst. Inc., Cary, N.C.

Seip, D.R. and F.L. Bunnell. 1985. Nutrition of Stone's sheep on burned and unburned ranges. J. Wildl. Manage. 49:397-405.

Short, H.L. and E.E. Remmenga. 1965. Use of fecal cellulose to estimate plant tissue eaten by deer. J. Range Manage. 18:139-144.

Short, H.L. 1981. Nutrition and metabolism, p. 99-127. In: Olof C. Wallmo (ed.), Mule and black-tailed deer of North America. Univ. Nebraska Press, Lincoln, Neb.

Weeks, H.P., Jr, and C.M. Kirkpatrick. 1976. Adaptations of whitetailed deer to naturally occurring sodium deficiencies. J. Wildl. Manage. 40:610-625.

Weller, R.A. 1969. Rates of fermentation in sheep grazing pastures. Brit. J. Nutr. 21:97-107

Wofford, H., J.L. Holechek, M.L. Galyean, J.D. Wallace, and M. Cardenas. 1985. Evaluation of fecal indices to predict cattle diet quality. J. Range Manage. 38:450-455.

Work, E. and D.L. Dewey. 1953. The distribution of 2,6 diaminopimelic acid among various micro-organisms. J. Gen. Microbiol. 9:394-406. 